Our Nature (2003) 1

Distance between the two adjacent filaments showed variation at different regions of the anterior and posterior hemibranchs. The distance between adjacent filaments was minimal at the point where the hemibranchs made a right angle turn to their dorsal regions.

In $X$. cancila (Ham.) each secondary lamella was wider at the efferent side than that of its afferent side. The secondary lamellae of the base and middle parts were almost identical as far as their profile and area were concerned. Difference was found in the diameters of afferent and efferent filament arteries. Diameters of these arteries were comparatively greater towards the base of the filaments. The secondary lamellae of the tip regions were

\section{References}

Bevelander, G. 1935. A comparative study of the branchial epithelium in fishes with special reference to extra renal excretion. $J$. Morphol. 57: 335-351.

Goodrich, E. S. 1930. Studies on the structure and development of vertebrates. Macmillion \& Co., London.

Hughes, G. M. and M. Morgan 1973. The structure of fish gills in relation to their respiratory function. Biol., Rev. 48: 419-475. comparatively smaller in size and the sections lacked the interbranchial septum. It was also arranged alternately on the sides of the primary lamellae and their number per unit area was found to be higher.

It is evident that the general pattern of gill structure of $X$. cancila (Ham.) does not deviate from the principal plan. However the morphology of the four-gill arches show dissimilarity in their length and possession of number of primary gill lamellae in the first, second, third, fourth gill arches. It may be due to elongated snout like jaws and the reduction in the length of gill arches from the first to fourth.

Anjali Devi Dahal

Department of Zoology

P. G. Campus, Biratnagar

Hughes, G. M. and J. S. D. Munshi 1968. Fine structure of the respiratory surface of an airbreathing fish, the climbing perch, Anabas testudineus (Bloch). Nature. 219: 1382-1384.

Subba, B. R. 1999. Structure and function of respiratory organs of hill stream fish, Glyptothorax telchitta. Ph. D. Thesis, T. M. Bhagalpur University, Bhagalpur, India

\title{
8. Molluscan Diversity of Koshi Tappu Wildlife Reserve and its Surrounding Area
}

Koshi Tappu Wildlife Reserve (KTWR) was established and gazetted in 1976, primarily for the protection of last remnant population of wild water buffaloes (Bubalus bubalis arnee). It is extended between $86^{0} 55^{\prime}-87^{0} 05^{\prime} \mathrm{E}$ longitude and $26^{0} 34^{\prime}-26^{0} 45^{\prime} \mathrm{N}$ latitude. It lies in the floodplain of Saptakoshi River which stretches up to Indian border in the southern part. It covers total area of 175 sq. km. which includes some parts of Sunsari, Saptari and Udayapur districts, the
Eastern Development Region of Nepal. It covers large volume of wetlands, so it is designated as a wetland of international importance and added to Ramsar list in $17^{\text {th }}$ Dec, 1987 (IUCN 1990).

A review of literature regarding the molluscan diversity of Nepal reveals that there is scanty information. However, recently Subba and Ghosh $(2000,2001)$ has made reports on molluscs of Nepal. Majupuria (1981-1982) has reported a few species of land and freshwater 
Our Nature (2003) 1

molluscs from Kathmandu valley. Investigation on different aspects of population dynamics of freshwater snails have also been carried out by Yadav et al. (1980) and Pfeiffer et al. (1990).

Koshi Tappu Wildlife Reserve and its adjoining areas, viz. Madhuban, Kushaha and Haripur Village Development Committees were selected for the study site. The specimens were collected up to six months from $5^{\text {th }}$ May 2002 to $5^{\text {th }}$ Nov 2002. The rivers, wetlands and paddy fields were the main collection sites of freshwater molluscs; while the land molluscs were collected from shady and moist places. During the collection, different instruments like nylon scoop, nets, forceps, rubber globes, polythene bags and plastic containers were used to keep the specimens. Live specimens were preserved in $70 \%$ alcohol and 5\% formalin. The specimens were identified with the help of available literature (Preston 1915, Subba Rao 1989).

During the study period nine species were recorded. Among them seven were fresh-water and two were land molluscs. Among the freshwater, five were gastropods and two were bivalves species. Land molluscs were gastropods (Table 1).

Table 1. Molluscan list of Koshi Tappu Wildlife Reserve

\begin{tabular}{|l|l|l|}
\hline Family & Scientific Name & Habitat \\
\hline Veronicellidae & Laevicaulis sp. & Terrestrial \\
Stenogyridae & Achatina fulica(Bowdich) & (B) \\
Lymnaedae & Lymnaea accuminata (Lamarck 1822) & Fresh-water \\
Lymnaedae & Lymnaea luteola (Lamarck 1819) & $"$ \\
Thiairidae & Brotia costula (Muller 1774) & $"$ \\
Unionidae & Lamellidens marginalis & $"$ \\
Viviparidae & Bellamya bengalensis f. typica & $"$ \\
Planorbidae & Indoplanorbis exutus (Deshayes 1834) & $"$ \\
Amblemidae & Parreysia flavidens & $"$ \\
\hline
\end{tabular}

\section{Acknowledgement}

The author is grateful to Dr. Bharat Raj Subba, Head of the Department of
Zoology, Post Graduate Campus, Biratnagar, for identification of specimens.

\section{Damodar Thapa \\ Post Graduate Campus Biratnagar}

\section{References}

IUCN 1990. Directory of Wetlands of International Importance, Ramsar Convention Bureau, Switzerland.

Majupuria, T. C. 1981-82. Wild is Beautifu: Introduction to Fauna and Wildlife of Nepal, S. Devi, Gwalior, India, pp. 507

Pfeiffer, M., S. Sharma and B. M. Dahal 1999 . Age and population structure of Freshwater Mussel in the Lowland Rivers of Nepal. Proc. of III Nat. Conf. on Sc. and Tech. pp. 1371-1377.

Preston, H. B. 1915. The Fauna of British India including Ceylon and Burma. Mollusca
(Freshwater Gastropoda and Pelecypoda). Taylor and Francis, London, pp.i-xi+ 244.

Subba Rao, N. V. 1989. Handbook of Freshwater Molluscs of India.Publ.Zoological Survey of India, Calcutta.

Subba, B. R. and T. K. Ghosh 2000. Some freshwater molluscs from eastern and central Nepal.J. Bomb. Nat. His. Soc. 97 (3): 452-455.

Subba, B. R. and T. K. Ghosh 2001. Land molluscs from eastern and central Nepal. J. Bomb. Nat. Hist. Soc. 97(4): 58-61

Yadav, U. K. R., S. B. Karki and P. N. Mishra 1980. Population studies of freshwater snails of a lake \& three ponds of Kathmandu valley, Nep. J. Nat.l His. Mus. 4(1) 